\title{
The Meaning of "Epistemology" Science, Common Sense and Philosophy according to Émile Meyerson
}

\author{
Frédéric Fruteau de Laclos \\ Université Paris 1 Panthéon-Sorbonne (France) \\ Centre d'histoire des systèmes de \\ pensée moderne (E1 1451) \\ Frederic.Fruteau-De-Laclos@univ-paris1.fr
}

DOI 10.1515/kjps-2017-0010

Argument Émile Meyerson (1859-1933) is an epistemologist, in the French meaning of the term: he himself introduced the word in French as a synonymous for "philosophy of science" in his major book of 1908 Identity and Reality. First educated as a chemist, Meyerson discovered philosophy while reading Auguste Comte's Cours de philosophie positive. However, he strongly rejected Comte's positivism: metaphysics, he said, penetrates science and even common sense; men, whether they are scientists or not, are interested in finding a cause behind the stream of phenomena. This anti-positivism is justified in so far as Meyerson used the same method and pursued the same goal as Comte: the philosopher must practice an "a posteriori analysis of the products of thought", so as to determine the laws of human mind. Consequently, Meyerson's work is not a mere philosophy of science, it is more than an "épistémologie" in the French sense. Its ambition is to reach the intellectual basis of all thought. The philosopher can resort to the resources of metaphysics to reach the psychological foundations of humanity, when he reflects on the historical products of thought. He establishes the transcendent or metaphysical logic involved in the process of thought. Meyerson's work consequently deserves the name its author eventually gave to it in his posthumous Essais: a "philosophy of intellect". But is such a philosophy wide enough to embrace the meaning of all the products of human thought? It seems that Meyerson was embarrassed and limited by his very starting point, namely Comte's system. I argue that scientific or common conceptions may need more than the anti-positivist claim of the preservation of one substance behind phenomena. Truth to tell, men generally tend to identify a large and rich configuration of causes or substances. Only such architectonics can give an idea of what people mean by invoking their "vision of the world". 


\section{Introduction}

The English word "epistemology" is equivalent to the German term Erkenntnistheorie or to the French expression "théorie de la connaissance" (theory of knowledge). It takes knowledge as a general category whose specifications are respectively common and scientific. But when the French word "épistémologie" first appeared, it was defined as a synonymous for "philosophy of science". The new discipline was specifically dedicated to scientific knowledge and explicitly rejected the idea of a common knowledge. There is no continuity, but an "epistemological break" ("coupure épistémologique") between science and common sense, which is a kind of ignorance more than a special sort of knowledge. Indeed, as Gaston Bachelard and his followers argued, we should rather talk of a simple doxa, whose productions are misleading or empty ("I'opinion pense mal, elle ne pense pas"). Nevertheless, at the very moment the philosopher Emile Meyerson noticed that "épistémologie" meant "philosophy of science" in French, he added that his own intellectual position was in accordance with the English "epistemology" or the German Erkenntnistheorie:

The present book belongs, by reason of its method, to the domain of the philosophy of science or epistemology, to use a word sufficiently appropriate and now becoming current. We have, however, in our research been guided by certain conceptions foreign to this domain. [...] It has seemed to us that [...] not only vision but the perception of the external world in general ought to set in motion the processes which nature would disclose, at least in part, if one were to scrutinize those by whose aid conscious thought transforms this image. In other words, we believe that the best way to solve the problems concerning common sense consists in examining the methods followed by science'.

Commenting in the Preface of a second edition the discussions aroused after the publication of his masterwork Identity and Reality, Meyerson wrote: "And this way what could first seem to be a pure epistemological problem immediately broadens itself into a problem of theory of knowl-

1 É. Meyerson, Identity and Reality (IR), New York: Dover Publications, translated by Kate Loewenberg, 1962, p. 5. 
edge"2. I would like to come back to Meyerson's conception of science and common sense, in so far as this "epistemology" particularly deserves the attention of psycho-sociologists. First, the philosopher considers scientific theories as the products of a tendency of human mind, whose activity consists in the discovery of concrete things behind the flow of the becoming. Like his contemporary Lucien Lévy-Bruhl, Meyerson attempts to infer the nature of our psychological functions from the empirical data delivered by the recently born social sciences (sociology and ethnology for Lévy-Bruhl; history in the case of Meyerson). Such a methodological relationship has an obvious reason: Lévy-Bruhl and Meyerson, who were close friends, both inherited from Auguste Comte, the French inventor of sociology ${ }^{3}$.

But this philosophy of science - this "épistémologie", as French people say - is also an "epistemology", that is to say a general theory of knowledge. As such, it involves a comprehensive analysis of common sense. Common sense represents the meaning that we, considered as the members of a historical community, give to the objects around us. Now, common sense obeys the same principles as science. The reason why we spontaneously tend to transform our sensations into stable and durable objects is that we believe that, thanks to such things or causes, we will be able to give a reason to the stream of phenomena continuously affecting our senses.

\section{Science and Objects}

First educated as a chemist, Emile Meyerson (1859-1933) discovered philosophy while reading Auguste Comte's Cours de philosophie positive. However, he strongly rejected Comte's positivism: metaphysics, he said, penetrates all science, and scientists are interested in finding a cause behind the stream of phenomena. This anti-positivism is justi-

2 É. Meyerson, Identité et réalité, Paris: Vrin, 1951, p. XI: "Et c'est ainsi que ce qui peut paraître d'abord un pur problème d'épistémologie s'élargit immédiatement en problème de théorie de la connaissance". (Our translation: an "Author's Preface to the English edition" took the place of Meyerson's Preface of the second edition of his book.)

3 See L. Lévy-Bruhl, La philosophie d'Auguste Comte, Paris: Alcan, 1900 and É. Meyerson, Lettres françaises, Paris: CNRS-éditions, 2009, É. Meyerson à L. Lévy-Bruhl, 12 avril 1921 , p. 393-394. 
fied in so far as Meyerson used the same method and pursued the same goal as Comte: the philosopher must practice an "a posteriori analysis of the products of scientific thought", so as to determine the laws of human mind. Consequently, Meyerson's work is not a mere philosophy of science. Its ambition is to reach the intellectual basis of all thought. The philosopher can resort to the resources of metaphysics to reach the psychological foundations of humanity, when he reflects on the historical products of thought: he establishes the transcendent or metaphysical logic involved in the process of thought. This logic leads him to discuss symbolical logic and human sciences at the end of his life. Meyerson's work deserves the name its author eventually gave to it in his posthumous Essais: a "philosophy of intellect".

Taught in Heidelberg by Bunsen in chemistry and by Hermann Kopp in the history of chemistry, Meyerson admitted that his reading of Comte's Course on Positive Philosophy was responsible for his reorientation from chemistry or history of chemistry to philosophy of chemistry and more broadly of all sciences. For he realized that, if he had to accept Comte's principles for the history of science, he was lead to epistemological conclusions in complete contradiction with Comte's philosophy of science: scientists never prevent themselves from speculating on the causes of phenomena. Although they professed their acceptance of positivist methodological principles in Prefaces or Introductions, the way they conducted their demonstration, their use of metaphysical hypotheses in the process of deduction, all those features contradicted their initial allegation (their "profession of faith") ${ }^{4}$. Indeed, Meyerson's first and constant philosophical point is an anti-positivist one. From the beginning to the end of his career, from the first book to the last, from Identity and Reality to Du Cheminement de la pensée, he claims his opposition to Comte.

But we shall insist on the exact meaning of this philosophical opposition to Comte's anti-metaphysics. Meyerson's opposition to Comte's opposition to metaphysics is nothing but the positive affirmation of those characters Comte denies to science. By rejecting Comte's opposition to metaphysics, Meyerson asserts what Comte denied. But, precisely, he

4 H. Metzger, "La philosophie d'Emile Meyerson et l'histoire des sciences", La méthode philosophique en histoire des sciences, Textes 1914-1939, Paris: Fayard, 1987, p. 99-100. 
does not say more than what Comte said. He takes Comte's definition of "metaphysics" and declares, against Comte, but in perfect agreement with the terms of the definition, that they can be applied with profit to the history of science. In my opinion, such a preliminary definition of metaphysics, such an implicit acceptance of the positivist definition of metaphysics - is a pity for the future of philosophy. Let us recall this meaning of metaphysics, and the correlative task assigned by Meyerson to philosophy.

For Comte, the progress of sciences obeys the law of the three stages of the human mind. According to this law, metaphysics is nothing but a transitive stage, between the theological stage on the one hand and the positive one on the other. In the metaphysical stage, science describes phenomena in terms of cause. Scientists still examine the "mode of production" of reality. A cause is the thing (in French, la "chose") presupposed by the human mind at the very origin, at the very ground, of our sensations. The phenomena are only seen as the effect of such a deep, profound and rational cause in "things themselves". But in the positive stage, which chronologically and axiomatically follows the previous one, scientists have abandoned considering causes. They do not "feign any hypotheses", as Newton wrote in a passage of the General Scholium of his Principia:

An attempt has sometimes been made to make this hypotheses non fingo a sort of profession of faith, as if Newton had declared the search for the explicative hypothesis illegitimate. (...) Now the text of the very passages which we just cited proved very clearly that Newton had sought for an hypothesis without finding it ${ }^{5}$.

At last, they are delivered from the negative effects that the theological stage continued to express in science through the metaphysical attempts.

Meyerson rebels against this negative conception of metaphysics. If you do not take into account the search for metaphysics in the scientific explanation of reality, he claims, you will never understand the history

$\overline{5 \quad I R, \text { p. 49-50. }}$ 
of science. As he shows in his first book, Identity and Reality, for the epistemologist, the postulation of causes behind the diverse elements of becoming, at the very source of sensations, represents the key of intelligibility for the succession and duration of all scientific explanations. The search for things or causes remaining identical to themselves in time is the psychological condition of possibility of any progress of thought. Underestimating the influence of metaphysics will never allow the historian to explain why scientists imagined mechanism, atomism or the Einsteinian theory of relativity. Meyerson demonstrates that the idea of an elastic atom, as well as the hypothesis of a dynamic center of forces, satisfy neither clear logic nor empirical facts:

(...) not only the elasticity but also the hardness of substances require explanation. (...) If we suppose that their elasticity is due to motions of a more tenuous medium, since we shall have to explain in its turn the elasticity of the medium, we shall have to imagine another more tenuous still, and so on without end. (...) When we speak to me of atoms I do not conceive of them distinctly, and I attribute to them a sort of unity quite ideal. Then their rigidity baffles me less, although, at bottom, the difficulty is the same. But here I feel it immediately, and I realize that the hard atom demands an explanation as much as the elastic one ${ }^{6}$.

From the point of view of our imagination the dynamic representation is even incontestably inferior to the corpuscular representation ${ }^{7}$.

And the Einsteinian attempt to reduce the world to a quadri-dimensional continuum of time and space is somehow paradoxical. Yet, scientists have never abandoned the idea that such "things" are the source of the stream of phenomena. The search for causes and the discovery of such "things" ground the heart of the "faith in scientific explanation". Take it away (like a historian or an epistemologist), and the past, but

\footnotetext{
$\overline{6 \quad I R, \text { p. } 70-71 .}$

$7 \quad I R$, p. 76.
} 
also the topical course of science, will appear as a perpetually self-contradictory advance of thought.

So, two mental movements have to be considered from Comte's point of view. Legal relationships, numeric links between sense data, are first transformed into things. "Energy is nothing but an integral". Yet, scientists convert it into a substance. In the same way, "mass" expresses the material effect of bodies on one another. Nevertheless, it is affected to a single being as its own property:

(...) mass no longer appears to us as a relation between two bodies, but as a coefficient becoming attached to each particular body, as a property of the body, which causality is then charged with transforming into a substance. But it is not the same with energy; it remains a relation, and if one wishes to conceive of it as a property, it will be the property of a system and not that of a body. (...) energy is only an integral. Nothing more remains but a statement for the principle of the conservation of energy: there is something which remains constant ${ }^{8}$.

Then a second operation interferes: the substance thus composed is projected at the base of phenomena. The intellect externalizes this artificial (built, constructed) identity outside the mind, making it a part of nature itself. Metaphysics is the name given to the identification, which consists in these two spiritual movements: the transmutation of legal schemes into things identical to themselves in time, followed by the "hypostasis" of that thing into reality. In Meyerson's writings, "ontology" indicates nothing more than the spontaneous realism relative to the objects of science. The problem raised in such circumstances is this: cannot metaphysics be anything else than the realization of scientific reasons? What should philosophy really be?

Meyerson's thesis embodies a sharp opposition to all kinds of positivism (including logical positivism) and operationalism. In Du chemine-

$\overline{8 \quad I R, \text { p. 207-209. }}$ 
ment de la pensée, he proposed arguments against Schlick and Carnap ${ }^{9}$, but he was also indirectly confronted with Bridgmann's position in the United States. George Boas wrote a whole book under this operationalist influence ${ }^{10}$, before turning to the history of ideas and writing books with Arthur Lovejoy. Space and identity are essential to scientists, but you will not only find legal relations or abstract operations in science. Meyerson highlights the decisive influence of $a$ subjective meaning dealing with a world of concrete objects. The epistemologist builds an anthropology, he reveals the deep mental tendencies of science involving different Weltanschauungen depending on the "things" identified in each historical case.

Philosophy has to make that spontaneous tendency to metaphysics explicit. It is not a mere hobby for idle philosophers, but a necessity for science itself. Thanks to a long tradition of metaphysical discussions, from Plato and Aristotle to Husserl, Bergson and Whitehead, philosophers are trained to be confronted with metaphysical problems. Consequently, they are particularly able to expound the ontological presuppositions of scientific theories. One of the most striking examples of that advantage of philosophers on scientists in the revelation of their spontaneous metaphysics certainly lies in Einstein's testimony. As he told General André Metz, who reproduced the quotation in his book on Meyerson's philosophy: "I did not know I was a metaphysician, but after reading Meyerson's book, I must confess it: I am possessed by the same 'demon of theory' as Descartes and that first astonished me in his system of metaphysic deduction"11.

What may be applied to natural science is extended to logic, psychology, and even history and sociology in Meyerson's last book, his "swan song" (his "chant du cygne"), Du cheminement de la pensée. Here again,

$9 \quad$ On Meyerson and the Vienna Circle, see F. Fruteau de Laclos, "Émile Meyerson et le Cercle de Vienne: conception anthropologique des sciences contre conception scientifique du monde", Austriaca, 63, 2006, p. 85-98 and F. Fruteau de Laclos, Émile Meyerson, Paris: Les Belles Lettres, 2014, p. 117-128.

10 G. Boas, A critical Analysis of the Philosophy of Emile Meyerson, Baltimore: The John Hopkins Press, 1930.

11 A. Metz, Meyerson, Une nouvelle philosophie de la connaissance, Paris: Alcan, 2nd ed., 1934, p. 179-180. 
the philosopher's task consists in revealing the ontological meaning that a subject of knowledge confers to the world of objects he is reflecting on.

\section{Common Sense and Knowledge}

According to Meyerson, common sense has to be studied as a kind of mental entities which, before being disqualified, are to be qualified, that is to say to be considered for themselves. The epistemologist shows it in the long last chapter of Identity and Reality'2. Truth to tell, as he confessed to his parent Ignace Meyerson, who founded a "comparative, objective, historical psychology", he first wrote this chapter, even before having thought of the chapters on the philosophy of science ${ }^{13}$. Indeed, we should say that Meyerson is almost an anthropologist who attempts to study the principles of human nature without judging the products of such principles. If we had to compare him to a great philosopher of the tradition, we would say that he has more connections with Aristotle than with Plato. In Aristotle's De Anima (III, 1, 425a30-425b5) common sense is first defined in a psychological way as the faculty thanks to which the sensations of each sense are coordinated. Sensations, for Meyerson as for Aristotle, are the more fundamental elements that philosophy may exhibit when it tries to analyze our ideas in common sense as in science. All our knowledge is nothing but our relation to the relations between sensations. We know the things as they appear to us and as they are coordinated by us, but not the things themselves or in themselves (the famous philosophical Ding an sich): "When it is a question of sound and color, it is understood that what I place outside of me, by virtue of common sense, is a simple hypostasis of my sensation"14.

A phenomenon is a mere sensation. But, by saying that, we do not talk as in the everyday life. Scientists themselves do not use such a language.

\section{$12 I R$, Chapter 11.}

13 É. Meyerson, Lettres françaises, op. cit., É. Meyerson à I. Meyerson, 30 décembre 1931, p. 627: "[...] je ne suis pas réaliste. Je suis, tout au contraire, dans le temps, parti d'un idéalisme très avancé, et je n'ai jamais complètement abandonné cette manière de voir. J'ai même essayé, il y a plus d'un quart de siècle, de présenter les opinions que j'ai exposées dans le $11^{\mathrm{e}}$ chap. d'Identité et réalité [sur le sens commun], en langage idéaliste".

14 IR, p. 361. 
Only philosophers can say that. Just turn to your neighbor and ask him "on what are you seating right now?" He will never admit it is a complex of sensations, but "a chair", which is a "thing" composed of different material elements which are substantial and do not change through time. Such an object is, from everybody's point of view, the very cause (and not the effect) of his sensations: "Common sense is certainly an ontology; it clearly affirms the existence of external objects and is very far from supposing that the existence depends on our consciousness"15.

In the same way, ask the electrician or even the physicist what "there is" in the electrical outlet. He will say that it is something he calls "electricity", or some microscopic things he calls "electrons" ${ }^{16}$. Unless you are spontaneously a metaphysician, you will conceive no skeptical doubt concerning the existence of the external things you are confronted with, even if you may have problems to render precise their essence:

(...) in forming these concepts of external objects according to the system of common sense, our understanding has followed no other rules than those which we recognize in scrutinizing the operations of science. It is always the principle of causality, the tendency to see, under the pressure of a need for explanation, everything persisting without change (...). Causalism - if it is permitted to use this term is not a privilege of the scientist. It is the characteristic of man. It will help in no way to try to brush aside this "ontology"17.

It is true that philosophers tend to reduce things to phenomena and phenomena to sensations, that is to say substances to relations, and theses relations to "realities" relative to our sensitive and cognitive capacities. Yet, philosophers have to recognize that common men, scientists and even themselves when they wake up in the morning or when they stop discussing with their colleagues, believe in the reality of the things

$15 \quad I R$, p. 357.

16 É. Meyerson, Réel et déterminisme dans la physique quantique, Paris: Hermann, 1933, p. 22.

17 IR, p. $362,364$. 
they see, touch or use. We all have an invincible tendency to materialize or to objectify our sensations. We project them outside us; we make things thanks to them. This tendency is common sense itself. Common sense produces through perceptions the unity of a thing from the multiple sensations issued of a single sense or of different senses. For instance, it assures the temporal continuity of the existence of this chair; but it also gives the perception of this chair as both brown and confortable. Quoting the famous French philosopher Henri Bergson, Meyerson says that:

Perception is, therefore, a complicated operation. Memory plays a considerable role in it: "consciousness means memory", "there is no perception which is not mingled with recollections", says Bergson, and mingled to such a degree that "perceiving ends in being only an occasion for remembering". These memories, moreover, are often those of several senses ${ }^{18}$.

Common sense is the first "objective" or "real" product of the human tendency to materialize sense data. It is followed by a large class of other objectifications:

(...) as soon as we advance a little in research, the world of common sense immediately appears to us what it is in reality - to wit, an introductory and very imperfect sketch of a scientific and metaphysical system ${ }^{19}$.

Common sense is a "very imperfect sketch". Do this mean that Meyerson disqualified and criticized common sense, by insisting on the clear superiority of the "things" that scientists identify? It is not the case. Maybe the things projected by scientists (movement, energy, mass, force, etc.) are less imperfect and more precise objectifications. Yet, the fact remains that they are first objectifications of ideas. And the mechanism of such a tendency, the formal identity of all objectifications, is the

\footnotetext{
$18 \quad I R$, p. 354.

$19 I R$, p. 364.
} 
essential point to Meyerson. Meyerson's epistemology consists in the philosophical analysis of this common mental operation, rather than in the affirmation of a hierarchy between the different levels of reality thus objectified. The gap between common sense and science, and the superiority of science on common sense, is less significant than the identification of an "analogy" in the cognitive process. From such a point of view, science is a mere "prolongation" of common sense:

In this chapter we shall try to show that while it is true that what we call concepts of common sense are fashioned by an unconscious process, the process is otherwise strictly analogous to the operation by which we form scientific theories; that here, too, the causal tendency, the principle of identity in time, plays a preponderant role and that from this point of view common sense is an integral part of science; or, inversely, that science is, as has been said, - but with perhaps a slightly different meaning - only a prolongation of common sense ${ }^{20}$.

Consequently, Meyerson is more interested in identifying the way common sense psychologically and sociologically works than in pointing its imperfections:

The word [of common sense] is, moreover, well chosen. The system simplifies relations with our fellow-men. It is of little importance, from this point of view, whether our concepts are more or less adequate to things; since errors are the same in the case of other men, they are eliminated when we communicate with them. (...) we admit that the agreement of others and the usefulness of the communication confirm our inclination ${ }^{21}$.

Indeed, it is obvious that scientists proceed as any other men; they all work at constituting an authentic "scientific common sense":

\footnotetext{
$20 \quad I R$, p. 354.

$21 \quad I R$, p. 363.
} 
(...) mechanism is also like common sense in this respect, as Renouvier admirably perceived, that in reducing sensibility to certain elements, the most abstract of all, such as movement, resistance, penetrability, elements no doubt incompletely determined, but of which the concept is, nevertheless, constituted in somewhat the same way in all men, it becomes by the fact a means of facilitating communications, a kind of "scientific common sense"22.

Meyerson's ambition to study the "prolongation" of common sense into science does not mean that he considers scientific and common knowledge on the same level, as having an equal success. You can find such an interpretation - which is rather an extrapolation - in Gaston Bachelard and Gilles Deleuze ${ }^{23}$. But if Meyerson aims at not devaluating common sense, he does not wish in the same time at identifying common sense and science. To the contrary, his thesis of an analogy in the process of objectification involves a formal equivalence as well as a material difference between science and common sense. First of all, the "things" that scientists conceive and realize are more consistent things than the objects in the everyday life ${ }^{24}$. A scientific common sense emerges from theses postulations in physics or chemistry, which constitutes a deep ontology shared by a whole community during a certain time. We are very close here to what Thomas Kuhn called a "paradigm"; let us recall

$22 \quad I R$, p. 365.

23 See G. Bachelard Le rationalisme appliqué, Paris: Puf, 1949, p. 102-118 and Le matérialisme rationnel, Paris: Puf, 1953, p. 212-213; G. Deleuze, Différence et répétition, Paris: Puf, 1968, p. 286-293; Difference and Repetition, New-York: Columbia University Press, 1994, translated by Paul Patton, p. 329. On these interpretations, see F. Fruteau de Laclos, "Le sens commun pense-t-il? L'épistémologie, la raison et les normes", Normativités du sens commun, Cl. Gautier \& S. Laugier ed., Paris: Puf, 2009, p. 233-255.

$24 I R$, p. 372: "Let us now recall what we stated about scientific concepts of a very different order, such as mass, force, energy. These concepts in the beginning are evidently only relations. Mass is the coefficient which bodies manifest at the moment of mechanical action; force is only the cause for the acceleration, which is a difference of two velocities; energy is a concept still more complicated, impossible in certain cases to define its entirety. It is, moreover, a simple integral, characterising not a body but a system, and of which only the variations are studied. This does not prevent physics from manifesting the tendency to treat these concepts as real things. In certain respects the reality which is attributed to them is even superior to that which common sense assumes in objects created by it. Indeed the distinctive character of these last, perdurability, is here intensified". 
that Kuhn admitted in the Structure of Scientific Revolutions that he was influenced by Meyerson ${ }^{25}$.

We understand now the meaning of the "prolongation" of common sense into science. Scientists do not penetrate more deeply into the sense data; they do not demystify the mental procedures by which perception overtakes sensations and builds a common sense. To the opposite, science goes further than common sense; by radicalizing human operations, it both forgets its common starting point and proposes to our intelligence the most durable objects we can imagine ${ }^{26}$. In a way, science has something common; precisely its tendency to presuppose things at the level of phenomena. The belief in such things contributes to the birth of scientific communities. But nothing would have been possible if, in the first place, common sense had not have been a kind of science, in spite of its imperfections.

\section{Epistemology and Philosophy}

By reading Meyerson, we realize that the philosopher's investigation may be useful to understand science and common sense. But is this kind of reflection rich enough to characterize all the possible philosophical adventures of ideas? In Meyerson's work, philosophy seems to be reduced to anthropology. "Philosophy of the intellect" is even akin to a science of science: it tends to explain in an anthropological way any sort of scientific explanation in terms of metaphysical identifications. It identifies science thanks to the criterion of identity. But can all philosophy be identified to Meyerson's "philosophy of intellect"?

$25 \quad$ At Harvard, Kuhn Wrote, "I continued to study the writings of Alexandre Koyré and first encountered those of Émile Meyerson, Hélène Metzger, and Anneliese Maier. More clearly than most other recent scholars, this group has shown what it was like to think scientifically in a period when the canons of scientific thought were very different from those current today". (T. Kuhn, The Structure of Scientific Revolutions, Chicago: University of Chicago Press, 1970, p. v-vi). For Meyerson, a paradigm explodes as soon as a scientific genius proposes a new hypothesis - that is to say a new hypostasis - whose postulation allows more powerful deductions of phenomena. On Meyerson, Koyré and Kuhn, see F. Fruteau de Laclos, Émile Meyerson, op. cit., p. 128-137.

$26 I R$, p. 373: "Does science reverse this evolution of common sense? Does it penetrate through quantitative perception as far as the qualitative sensation? On the contrary, it accentuates the evolution and forces it to its utmost limits". 
The narrow limits in which Meyerson contains philosophy become obvious from the moment you consider his interpretation of Hegel, in Explanation in The Sciences. He studies the Encyclopedia of Philosophical Sciences in so far as it can be confronted with the empirical sciences. A recent French reader of Hegel, Emmanuel Renault, has praised Meyerson for his interest in the second part of the Encyclopedia, The Philosophy of Nature ${ }^{27}$. Until now, most commentators (except Meyerson $^{28}$ ) have read Hegel without paying attention to this work although it represents a third of the total system. Yet, we may deplore Meyerson's almost exclusive interest in this part of the system. Meyerson's works count too few references to The Science of Logic and The Philosophy of Mind $^{29}$. These books are taken into account as long as they enlighten the Hegelian treatment of sciences. Even in The Philosophy of Nature, speculative developments are most of the time analyzed for the confirmation they bring about the scientific process of identification. Despite

27 E. Renault, Hegel, La naturalisation de la dialectique, Paris: Vrin, 2001, p. 8-9.
28 É. Meyerson, Explanation in the Sciences (ES), Dordrecht: Springer Science+Business
Media, translated by Mary-Alice and David A. Sipfle, p. 269-270: "Of the amazing edifice
constructed by Hegel, whose outlines we of course have no intention of retracing, even in
the most general terms, the only thing that interests us is its logical and scientific part.
[...] as for its application to nature - which is a direct consequence of the Logic and to
which Hegel attributed such an eminent place, consecrating to it about one-third of the
abridged version of his system, which is what the Encyclopedia is - it is often barely men-
tioned. [...] Thus our study will have a specific and precise goal, and consequently it could
not result in a truly complete picture of Hegel's effort, even in this limited field. [...] But
perhaps also some of them will be willing to concede that this quite specific aspect is not
without importance for the general comprehension of Hegelian philosophy".

29 É. Meyerson, The Relativistic Deduction. Epistemological Implications of the Theory of Relativity (RD), Dordrecht/Boston/Lancaster: D. Reidel Publishing Company, translated by David A. and Mary-Alice Sipfle, With a Review by Albert Einstein and an Introduction by Milic Capek, p. 90: "In fact, Hegel was not content to recreate physical reality; he also intended to 'construct' the totality of man's spiritual activity in the same way. Death interrupted him in the midst of this truly gigantic project, but he nevertheless had the time to complete the philosophy of right, the philosophies of history and religion, esthetics, and the history of philosophy. [...] For Hegel, when giving a 'basic outline' (Grundriss) of his work as a whole in the Encyclopedia, first treated the Logic in one volume, then devoted a second volume to the Philosophy of Nature and a third to the whole of the Philosophy of Spirit, thereby indicating that he considered this third work to be, at most, equal in importance to the one that preceded it. In fact, the Philosophy of Nature is even more voluminous than the Philosophy of Spirit (and this seemingly trivial detail is not without importance for a man as systematic as Hegel). Therefore, the Hegelian deduction really is primarily concerned with physical reality and is thus comparable to the deduction of the relativists in this respect". 
his efforts to penetrate the complex architectonic of hegelianism and the dialectic motor of his progression (he himself admits his difficulties in this domain), Meyerson's point of view remains partial and biased (in French, "partial et partiel"), as he wrote in the Foreword of Du cheminement de la pensée $e^{30}$. Of course, one could say ${ }^{31}$, that Meyerson's identification of dialectic and identity is done on purpose, that is to say involves a justified criticism of the Hegelian notions of difference and contradiction. Difference has no reason to be self-contradictory, there is no necessity for difference to discover itself as identical to identity after its progression through self-contradiction: identity and difference remain two diverse and opposite moments of the process of knowledge. The human mind wants to identify the diversity of sense data, but reality resists: according to Meyerson, we shall not go beyond the irrational, despite Hegel's attempt with his Aufhebung.

But the correctness of the philosophical criticism does not prevent the impression that Meyerson does not fairly present the rich and wide frame of the system which lies behind the analysis of science and is extended beyond it. What is the place of God, in relation with science? Is Art inferior to Science, or does it have an equal dignity, as any other production of the human mind? Is there a way of accounting for the first moments of thinking, with universal categories such as "Being", "Non-Being", "Becoming"? Do these concepts established in the course of history of philosophy embody abstract and empty notions, and are they definitely overthrown by the mathematical functions created by scientists? Or, on the contrary, is it possible, useful and meaningful to describe science, as any other

30 É. Meyerson, Du cheminement de la pensée (CP), Paris: Vrin, 2011, p. 21 . For those difficulties and that partiality, see also ES, p. 271: "The impression made upon a present day reader by the work of Hegel is totally different. It is - one is forced to admit, in spite of the great respect one may feel for an otherwise so powerful mind - one of profound bewilderment. There is nothing that recalls the science of today, nor the science of the author's contemporaries (which was, moreover, moved by almost the same spirit), nor even genuine science of any period of human endeavor, for instance Peripatetic physics or the chemistry of the alchemists. It is as if someone presented us with a series of absurdly grimacing monsters where we expected to see human figures. Sometimes one begins to doubt and rereads several times to convince oneself that the phenomenon treated by the author is indeed the one known by science, so fundamentally different is his interpretation from anything that science imagines or has imagined".

31 That is what I did in L'épistémologie d'É. Meyerson, op. cit., p. 191-225. 
human theoretical practice, thanks to these general categories, or some others elaborated in a comparable metaphysical perspective? Meyerson, haunted by the process and the progress of science, does not answer these questions, and only mobilizes Hegelian categories to make the spontaneous ontology of science explicit.

The same lacks are found in the Meyersonian study of other speculative systems. Descartes is mostly read through the scientific theses expressed in The Principles of Philosophy:

Thus a modern physicist reading Descartes's Principles will feel no repugnance and even no astonishment (unless it be born of admiration) (...). Nevertheless, nothing is more certain than the fact that Descartes, no less than Hegel, tried to deduce reality from nothingness; he went even further along this paradoxical path than the German philosopher was later to do, since the reality he claims to have deduced is more detailed than Hegel's. Thus he purports to have succeeded in drawing from his premises, by pure reasoning, "the heavens, the stars, an earth, and even on the earth, water, air, fire, the minerals and some other such things, which are the most common and simple of any that exist, and consequently the easiest to know". Elsewhere he writes: I have "become so rash as to seek the cause of the position of each fixed star"32.

You will find no mention of the metaphysical purpose of the Meditations. For Meyerson, even the reference to God in The Principles of Philosophy personifies identity: the search for some thing remaining identical to itself is fulfilled in cartesianism with God, whose Presence ensures the world's perpetual recreation and self-preservation:

It is thus that motion, having become a state, transforms itself into an entity, a substance - that is, in the virtue of the principle of causality, our mind shows the invincible tendency to maintain its identity in time, to conserve it. 
(...) Consequently, Descartes has disclosed the essence of the principle in relating it to the "immutability of God", to the conviction that everything in nature persists. His, therefore, is the merit not only of having been the first loudly to proclaim the principle, but also to indicate its true foundation $^{33}$.

In the same way, Spinoza's Ethics interests Meyerson's project in its second part, devoted to the theory of knowledge, and there is not a word on the fifth part on God or the last one on Beatitude:

After Descartes, Spinoza, starting from the Cartesian principles and proceeding with the pitiless logic and that "metaphysical rapture" which was the characteristic of that prodigious mind, states this formula, the most absolute expression of the postulate of intelligibility: "The order and the connection of ideas are the same as the order and the connection of things"; he proves this proposition by using the "axiom" which compares effect to necessary, logical consequence. But Spinoza, who knew mathematics, was not a physicist and wisely abstained from applying this principle to science ${ }^{34}$.

Last, but not least, Meyerson finds a great part of his inspiration in Kant's writings. But his comment focuses on the Kantian deduction of nature in the First Principles from a reading of Newton's ideas on "phoronomy", "dynamics", "mechanics" or "phenomenology":

The true way was shown by Kant: there is, indeed, agreement between our understanding and reality, but this agreement is partial, since in the end we run against contradictions which we call antinomies. Reality is partially intelligible, and our scientific knowledge is mixed with $a$ priori elements and with others that are a posteriori. But,

\footnotetext{
$33 \quad I R$, p. 146.

$34 \quad I R$, p. 397.
} 
when it is a question of separating these elements from each other, a task Kant undertook in two admirable works, Metaphysiche Anfangsgründen der Naturwissenschaft and Vom Uebergange von den metaphysischen Anfangsgründen der Naturwissenschaft zur Physik, we can no longer follow the great philosopher to the very end. (...) Kant thinks that science admits of a pure part, and consequently is entirely a priori ${ }^{35}$.

Meyerson does not offer any general survey of the links between these "scientific" developments and their transcendental foundations in the Critique of Pure Reason. No attention is paid to the philosophical conditions of the possibility of Science, to the Analytic required by the rationalization of the World, and to the Dialectic this rationalization provokes. Meyerson has no idea (or feigns not to have any idea) of the problems raised by rational psychology, rational cosmology and rational theology. However, these problems conduce to giving a quite special meaning to the notion of "metaphysics" implied in the title of the First Metaphysical Principles of the Science of Nature. I found a single reference to "transcendental idealism", depending on the analysis of the theory of relativity, but it is superficial enough ${ }^{36}$.

Meyerson has a peculiar and biased vision of philosophy. He takes into account the systems liable to help him in expounding the spontaneous philosophy of science or common sense. But it is too easy, then, to claim the inferiority of the philosophers' deductions compared to those of the scientists. The point is that he has first admitted the sciences' criterion of explanation as an absolute one, just as if philosophers were concerned

$35 \quad I R$, p. 400-401. See also $I R$, p. 398: "The impotence of pure deduction stands out also in Kant's work. Kant, we shall presently see, did not believe in the entire intelligibility of nature and applied himself to the task of tracing a limit between what in science is derived from deduction and what is due to experience. Yet he was led to ascribe too much power to the first".

$36 R D$, p. 144: "Those who compare Kant and relativism most often stress the concept of time. Relativism, they tell us, shows that we cannot assume that the notion of time as we find it formed within ourselves can be the property of things themselves; it is thus only the form our mind attributes to them, which is certainly consistent with Kant's position. And they go on from there to state that, in general, the concept of reality resulting from relativity theory agrees completely with what Kant called transcendental idealism". 
with challenging scientists on their own field, namely the confirmation of precise prediction by empirical or positive facts. See for instance the attack against Bergson's conclusions ${ }^{37}$. Yet, perhaps philosophers are not particularly or not only concerned with that scientific mode of "explanation" and "confirmation". Perhaps they are not interested in the same facts as science, but in science taken as a fact among others, such as art, religion, etc., so as to trace proper philosophical (or cosmological) perspectives of their own.

My point is that Meyerson is not confident enough in the powers of philosophy or metaphysics. I would say, like Jean Piaget, that Meyerson was wrong to accept the way Comte puts the problem of epistemology. I will not insist on the same matter as Piaget, who criticized Meyerson for not considering that "action" could have a different meaning than the positivist one ${ }^{38}$. But like Piaget, I wonder whether Meyerson was not a

37 ES, p. 526-527: "However, the opposite danger, that of the philosophers' disregard for the results of science, is perhaps not entirely chimerical, even at the present time, as witnessed by the attitude of Boutroux and Bergson in the matter of the identity of light rays and heat rays. However natural the opinion of these two illustrious thinkers may be, however consistent with the tradition and the very essence of philosophic thought, it is certain that in rebelling against some of the findings of physics, they acted in vain. Whatever the value of philosophic knowledge, the philosopher must recognize that scientific knowledge is made of a different metal, is more solid than his own, and that if he takes on science head to head, he cannot win. And since it is perhaps not totally impossible that philosophy might once again win back something like its former position in the public favor, this truism is not an idle statement". On Meyerson and Bergson, see F. Fruteau de Laclos, L'épistémologie d'É. Meyerson, op. cit., 137-190.

38 J. Piaget, "La causalité selon E. Meyerson", in Les théories de la causalité, Paris: Puf, 1973 , p. 152-153. Comte judged that action was at the base of any scientific explanation. "Science, hence prevision, prevision hence action". Against such a pragmatic view, Meyerson asserted that science had a different aim than pragmatic adaptation to the circumstances. Yet, Piaget says, Meyerson has not seen that action could be the support for the genesis of pure intellectual deduction. Without action, you will never explain how pure deduction can be produced by an intellect. The exact correlative and progressive adequation between a subject and its objects will never be understood if one does not take into account the role played by action, which is precisely the motor ("ressort") of such an adaptation. Indeed, "psychology" does not have the same meaning for both philosophers. Piaget's genetic epistemology aims at underlining the process of acquisition of knowledge, and the increase in the precision of knowledge through history. But Meyerson is not interested in such a psychological derivation of the products of thought. His "philosophy of the intellect" is a speculative deduction of scientific theories. The problem is to discover the reasons why scientific hypotheses are accepted, and first asserted, sometimes in spite of the experimental proof. Piaget tries to expound a genetic derivation of truth and its progress. Meyerson attempts a philosophical explanation of theories, particularly of false and illogical theories. On Meyerson and Piaget, see F. Fruteau de Laclos, Le cheminement 
victim of his starting point, namely the system of Comte's positivism: he uses a definition of metaphysics that is too restrictive, and the restriction is due to Comte's initial influence on him. As I said before, Meyerson's philosophy first aims at apprehending the meaning put by scientists in their theories, and projected on the world itself. Meyerson's purpose consists in explaining the meaning of theories: the formulation of any hypothesis relies upon the general form of identity. The philosophical postulation of identity is what makes the difference between Meyerson's very first works in the history of science, and the later works devoted to the philosophy of science. Such a philosophy, I repeat, will always be useful against all kinds of reductionism, whether you consider positivism or operationalism. This way, the investigation leads you to a special kind of "theory of knowledge", to an "epistemology" enlarged by psychological or anthropological perspectives ${ }^{39}$. But are these perspectives wide and rich enough to embrace all the claims and the results of philosophy itself, even on a psychological or an anthropological point of view?

Meyerson had the same flaw in his philosophical training as the scientists whose flaws he criticized. Indeed, he began as a scientist, and he learned philosophy by his own means:

What deeply satisfies me is the things you say about the "metaphysics" of science. I could feel, in your previous letters, that there was here, between us, something unclear that is now cleared. For my own, I understand how far my classification was vicious, in so far as it could give birth to a misunderstanding. I should have better using the term objective you suggested. There is here, I think, as far as I am concerned, a kind of idiosyncrasy which comes from my primitive philosophical education - I am,

de la pensée selon É. Meyerson, Paris: Puf, 2009, p. 29-32 and F. Fruteau de Laclos, "La epistemología de los psicólogos. Piaget y los Meyerson", Revista de historia de la psicología, vol. 34, n. 1, 2013, p. 59-80.

$39 E S$, p. 2: "In skimming through this summary table of contents, a reader at all familiar with our previous work (Identité et réalité, 2nd ed., Paris: Payot, 1912 [Identity and Reality, trans. Kate Loewenberg, New York: Macmillan, 1930]) will easily perceive that the two books have many points in common. Indeed, our area of research has remained unchanged: our concern is still the theory of knowledge. Nor has our method varied: we again seek, insofar as possible, to identify the essential principles of thought by considering the processes followed by scientific reason". See also $I R$, p. 5 ; $C P$, p. 42 ; É. Meyerson, Essais, Dijon: Association Corpus EUD, 2008, p. 83-84. 
as you know, an autodidact in that sort of knowledge - with Renouvier' writings. Now, this author had a real repulsion for the terms objective and subjective, that he considered as ambiguous. That is the instinctive reason why in some way I try not to use them. But it is certain that such a bias was a bad inspiration for me. I will try to correct myself on that point in a future occasion ${ }^{40}$.

You can notice that the confession to Harald Höffding is made at the occasion of a discussion on the meaning of metaphysics. Meyerson's first contact with metaphysics was obviously related to the status of ontology in science, as revealed by his initial and decisive opposition to positivism. He never really developed an authentic concern with the questions of "pure" philosophy. He did not attach much importance in his work to Descartes' God, Spinoza's beatitude, Kant's transcendental or Hegel's philosophy of mind. As Maurice Merleau-Ponty wrote, some epistemologists at the turn of the XXth century were incapable of reviving the "Great rationalism" of the Classics of the XVIIth century ${ }^{41}$. Whereas Descartes' scientific analysis of time and space opened out onto the depth of the metaphysical discovery of a deity, French epistemologists contented themselves with the description of scientific explanation as a reduction of time to space, and of space to unity. The possibility of scientific explanation received no philosophical explanation: it is a fact that nature is intelligible, but the reasons why it is the case stay out of sight and escape from intelligibility. A comparable drawing of the period was depicted by many other French authors of the following generation,

40 Correspondance entre Harald Höffding et Emile Meyerson, Copenhague: Einar Munksgaard, 1939, É. Meyerson à H. Höffding, 24 janvier 1925, p. 84: "Ce qui me satisfait encore très profondément, c'est ce que vous me dites au sujet de la 'métaphysique' de la science. Je sentais bien, par vos lettres antérieures, qu'il y avait là, entre nous, quelque chose d'opaque, qui se trouve éclairci à l'heure actuelle. Je comprends à mon tour que ma nomenclature était vicieuse, puisqu'elle a pu faire naître un malentendu. J'aurais certainement mieux fait de me servir du terme objectif, suggéré par vous. Il y a là, je crois, de ma part, une sorte d'idiosyncrasie qui provient de ce que j'ai fait mon éducation philosophique primitive - je suis, comme vous savez, autodidacte en ce qui concerne ce savoir - avec les écrits de Renouvier. Or ce dernier avait une véritable répulsion pour ces termes objectif et subjectif, les trouvant ambigus. C'est ce qui fait qu'instinctivement en quelque sorte, je les évite à mon tour. Mais il est certain qu'en l'occasion ce parti pris m'a mal inspiré. Je chercherai à m'en corriger dans une occasion future".

41 M. Merleau-Ponty, "Partout et nulle part", Signes, Paris: Gallimard, 1960, p. 238-245. 
such as Jean-Paul Sartre or the unfortunately - and unfairly - forgotten philosopher Etienne Souriau.

Meyerson aims at explaining the scientific tendencies involved in any theory, and particularly to isolate the instinct of identity and the correlative things identified in reality. But the problem is now: can all philosophy be identified with this psychology? It will not change anything if you oppose another nature of the scientific intelligence, as if reason should be defined by the search for diversity rather than by the extinction (and reduction) of it into identity. Léon Brunschvicg and Gilles Deleuze proposed that kind of alternative scheme ${ }^{42}$. But, in a way, it does not matter what definition you give to the procedures of science. For, whatever the solution you bring to this epistemological problem, it is not clear yet, whether philosophy is a pure commentary of science, or a reflection upon scientific conclusions as upon any other product of thought. As Étienne Souriau claimed, the philosopher gathers all possible facts into a concrete and coherent universe. He aims at building a consistent cosmology including science as one of its elements, but he exceeds pure positive facts to forge an accurate architecture of ideas corresponding to a general scheme of natural entities. He is not interested only in one peculiar substance considered as essential - a cause that would give the reason of things, the movement, the force, the energy, etc. - but in the connection of such a substance with all the other substances and things constituting the universe. Such a thesis is relevant for science as well as for common sense: common sense represents a similar architectonic of ideas, it likely creates complex theoretical conceptions of the world ${ }^{43}$. But you will not find a word in Meyerson's work on those experiences of thought that are likely experiences of reality:

Considering philosophy as a pleroma of works is not only giving it richness and substantial plenitude; it is preventing oneself from the risk of impoverishing and simplifying human thought in its history, so as to

42 See F. Fruteau de Laclos, L'épistémologie d'É. Meyerson, op. cit., p. 71-90.

43 I insisted on the importance of Souriau's ideas for the understanding of common sense in "Pour une epistemology française et la connaissance du sens commun", Revue de métaphysique et de morale, 2/2016, p. 177-191. 
force it at entering into the pathway of such or such linear dialectic which is a priori accepted - the Hegelian dialectic for instance.

And Souriau adds in a note:

We should compare on that point of view the works of L. Brunschvicg and those of É. Meyerson. We will see how the first, concerned with keeping the contact with all the variety, the complexity, the flexibility of the movements of thought, constantly pass the curve through the works; while the M. Meyerson's works make their reader much more attentive to global states of knowledge in such or such period, procedure which sometimes lead to great simplifications ${ }^{44}$.

In fact, there are other meanings than the scientific meaning, rich and extra-ordinary experiences of thought which are correlatively ontological processes. Consider Schelling and the scientific application his Naturphilosophie received thanks to the theories of Maxwell. They both constituted what we can call an "electro-philosophy" 45 . Meyerson contemplates something of that sort in Schelling's attention to diversity. In a way, Schelling defends a position equivalent to Bergson's. After the "Introduction to metaphysics", in The Creative Evolution Bergson denied science the right and the possibility to reach reality in its essential flow. Reediting this "Introduction" in 1934, he wrote:

By an increasing care for precision I was later led to distinguish more clearly between intelligence and intuition,

44 É. Souriau, L'instauration philosophique, Paris: Alcan, 1939, p. 52: "Considérer la philosophie comme plérôme des œuvres, non seulement c'est lui donner richesse et plénitude substantielle ; c'est se prémunir contre le risque d'appauvrir pour la simplifier la pensée humaine en son histoire, afin de la faire passer de force dans la filière de telle ou telle dialectique linéaire acceptée a priori - la hégélienne par exemple".; "Que l'on compare de ce point de vue les travaux de L. Brunschvicg et ceux de É. Meyerson. On verra comme le premier, soucieux de garder contact avec toute la variété, la complexité, la souplesse des mouvements de la pensée, en fait avec constance passer la courbe par les œuvres; tandis que les travaux de M. Meyerson rendent leurs lecteurs beaucoup plus attentifs à des états globaux de la connaissance à telle ou telle époque, ce qui entraîne parfois de grandes simplifications. See also É. Souriau, L'avenir de la philosophie, Paris: Gallimard, 1979, p. 95, 263.

45 G. Châtelet, Les enjeux du mobile. Mathématiques, physique, philosophie, Paris: Seuil, 1995, p. 156, 219-220. 
as well as between science and metaphysics. [...] I have been led, since the time of writing these lines, to restrict the meaning of the word "science", and to call more particularly scientific the knowledge of inert matter by pure intelligence ${ }^{46}$.

Bergson thus claimed a new kind of philosophical intuition of duration and diversity. But, according to Meyerson, this attention to reality is not absent from sciences. Schelling's speculative writings on the Philosophy of Nature show that diversity may and must be taken into consideration in a consequent reflection on science:

In one of his first works, Ideas for a Philosophy of Nature, he [Schelling] points out the analogy between his system of explanations and that of mechanistic physics in general and of Le Sage and Prevot in particular. So we see that Schelling, in many passages, appeals explicitly to scientific experimentation and openly avails himself of confirmations (real or imagined) that it had afforded him. All these works [System of Transcendental Idealism, An Exposition of my System of Philosophy], which from the standpoint of form thus resemble Hegel's subsequently published Naturphilosophie, nevertheless differ from it and also from the writings Schelling himself classified as philosophy of nature by their for the most part completely general tenor. In them we find the deduction of the three dimensions of space and also, simultaneously, that of the existence of magnetism, electricity, and the chemical process, as well as of gravitation and cohesion. But all the wealth of detail that characterizes what is properly called the philosophy of nature is lacking ${ }^{47}$.

Yet, Meyerson does not go very far in that way, he never penetrates the implication of philosophy into science so as to produce "electro-phil-

46 H. Bergson, The Creative Mind, New York: The Philosophical Library, 1946, translated by Mabelle L. Andison, p. 305 . See also my recent critical edition, H. Bergson, Introduction à la métaphysique, Paris: Puf, 2011.

47 ES, respectively p. 319, 321, 324 . 
osophical" schemes. Schelling's reflections only provide him with critical methodological remarks against Hegel's concept of identity:

This ambiguity, this hesitation between irreconcilable points of view, this mixture of "Spinozism", of general formulas radiating extreme idealism and of more precise claims deriving from realism and calculated to serve, in a manner of speaking, as a refuge for the mind as soon as the pitiless logic of the idealistic conception shocks it by consequences altogether too extreme - this is the very essence of our intellect. In that respect Schelling's doctrine is indeed more adequate for the intellect: it is, if we may venture to say so, more human than Hegel's. The fact that the philosophy of nature of the former seems immeasurably less shocking in relation to current ideas than that of the latter is only one particular aspect of this observation ${ }^{48}$.

I think a good idea of the relation between science and philosophy is given by Merleau-Ponty. Of course, most of the time, and particularly in his last writings, he did not consider the possibility of discovering authentic philosophical features inside science. Remember the first sentence of Eye and Mind:

Science manipulates things and gives up living in them. It makes its own limited models of things; operating upon these indices or variables to effect whatever transformations are permitted by their definition, it comes face to face with the real world only at rare intervals. Science is and always has been that admirably active, ingenious, and bold way of thinking whose fundamental bias is to treat everything as

48 ES, p. 340-341. See also ES, p. 312-313: "what actually constitutes 'the implicit driving force of this progression is still the terminus ad quem, the real world, at which knowledge must ultimately arrive' [Schelling]. However, the weakest point of Hegelian deduction remains the starting point itself: the transition between knowing and being, between the logic and the philosophy of nature". 
though it were an object-in-general - as though it meant nothing to us and yet was predestined for our own use ${ }^{49}$.

In the same manner, Merleau-Ponty claimed, in the long preliminary development devoted to science in The Visible et the Invisible, that there exists a scientific ontology, but that the recent difficulties with reality, in the quantum theory, dispense the philosopher from taking this metaphysics into account. Indeed, Einstein himself recognized his ontology depended on a personal and rationally unjustified choice. There is no reason, Merleau-Ponty concludes, to accept the scientists' metaphysics as the right one ${ }^{50}$. On this occasion, Merleau-Ponty makes his only explicit reference to Meyerson, in his course at the College de France on the quantum theory: he quotes Louis de Broglie quoting Meyerson on the (psychological) necessity of cartesianism and causalism, in spite of the scientific difficulties of accepting and proving it ${ }^{51}$.

But in other writings, like The Prose of the World, Merleau-Ponty evokes the possibility for the scientist to express the world and the necessity for the philosopher to embrace that kind of ontology in his reflection. The philosopher must "reflect on the reflection" of scientists, not to transcend or to criticize them, but to show their intimate link and their attachment to the world when expressing it. Like any other man, but particularly like an artist, the scientist expresses the world after he has been impressed by it. There is an inspiration (to be understood in a non metaphoric sense) immediately followed by an expiration of the world, coinciding with the artistic or the scientific works. See the analysis of Gauss in The Prose of the World:

It is not our intention to question the character of truth which distinguishes the propositions of exact science or the incomparability of the moment where, in recognizing

$49 \quad$ M. Merleau-Ponty, "Eye and Mind", translated by Carleton Dallery, Basic Writings of M. Merleau-Ponty, Thomas Baldwin ed., London \& New York: Routledge, 2003, p. 290.

50 M. Merleau-Ponty, The Visible and the Invisible, Evanston: Northwestern University Press, translated by Alphonso Lingis, 1968, p. 14-18.

51 M. Merleau-Ponty, La nature, Notes de cours du Collège de France, Paris: Seuil, 1994, p. 127 and L. de Broglie, "La physique quantique restera-t-elle indéterministe?", Nouvelles perspectives en microphysique, Paris: Flammarion, 1992, p. 115-143. 
a truth, I touch on something that did not begin with me and will not cease to signify after me. This experience of an event which suddenly becomes hollow, losing its opacity, revealing a transparence, and becoming forever a meaning is a constant in culture and speech. If one wished to challenge the experience, he would not even know any more what he was seeking. All that can be done is to discover its implications, in particular whether, in relation to speech, it is originary or derivative. More precisely, one can discover whether, even in exact science, there exists, between the institutionalized signs and the true significations they designate, an instituting speech which is the vehicle of everything ${ }^{52}$.

Merleau-Ponty also paid attention to the scientific ontology in "The Philosopher and Sociology" in the book untitled Signes ${ }^{53}$. Commenting the letters between Husserl and Lévy-Bruhl, Merleau-Ponty wonders, in a quite Meyersonian manner, whether the phenomenologist and the ethnologist agreed on the importance of the different "essences" of the world delivered in diverse Weltanschauungen. The answer is that the reflection of the anthropologist - leading to a cultural relativism - is interesting but not sufficient from a philosophical point of view. The philosopher's proper ambition is to reach some more essential, universal and absolute background, from which he would be able to take into account all metaphysics conceived by men. For Merleau-Ponty, this absolute philosophical ground consists in the consciousness of the role of perception, of the importance of my body and of those of the Others, in the construction of a common world. I do not know yet if I agree with the features of that philosophy, with the characteristics of that absolute ground. But, in my opinion, whatever the ontology you finally choose afterwards, the essential thing was to discover, and reclaim, behind Meyerson's analy-

52 M. Merleau-Ponty, The Prose of the World, Evanston: Northwestern University Press, translated by John O'Neill, 1973, p. 121.

53 M. Merleau-Ponty, "Le philosophe et la sociologie", Signes, Paris: Gallimard, 1960, p. 176-179. 
sis of science, the "possibility of philosophy". Merleau-Ponty used this expression as the title of one of his last courses at the College de France.

It is not a coincidence if both thinkers I mentioned, Souriau and Merleau-Ponty, were students of Léon Brunschvicg. As I argued in L'épistémologie d'É. Meyerson ${ }^{54}$, Brunschvicg was wrong concerning the nature of the spontaneous metaphysics of science, and concerning the direction of the evolution of that metaphysics, from common sense - rejected as a kind of ignorance - to the mathematical schemes produced by pure scientific geniuses. He thought science was moving towards more and more relativism and subjectivism, through the evolution of the process of measurement. On that point, he had to face (at the French Society of Philosophy in 1922) Einstein's objections, whose "theory of relativity" has nothing to do with a philosophical subjectivism. Yet, his work in the history of science offers an advantage: he never neglected the originality of the philosophical reflection on the products of science. He did not dissociate the study of Descartes' Principles from the analysis of the cogito. Kant's First Principles were read along with the "Transcendental Aesthetics". You can deplore the terms of the general thesis on epistemology (and regret that Bachelard inherited it, becoming a model for the "French tradition of epistemology"). But, as a philosopher and historian of philosophy, he taught his students never to separate the adventure of philosophical ideas from the creation of scientific schemes. He should be praised for that, and indeed inspired many important works on the borderline between science and philosophy ${ }^{55}$.

Formed as a chemist, Meyerson discovered epistemology under the influence of Comte's positivism. If he accepted Comte's method in the history of science, his own analysis of the products of thought led him to anti-positivist conclusions: the philosopher has to insist on the importance of identifying causes so as to produce scientific explanations. Consequently, it would be a non-sense of depriving scientists of metaphysics. Indeed, scientists make metaphysics as they breath, and separating

54 Op. cit., 72-83, 113-121.

55 See F. Fruteau de Laclos, "De l'architectonique en épistémologie. La philosophie des sciences selon Brunschvicg", Colloque De Brunschvicg à Bachelard, 6 février 2009 (http:// www.diffusion.ens.fr/index.php?res=conf\&idconf=2799). 
ontology and theory would be a catastrophe for science itself. Now, a question remains: is metaphysics nothing more than such a tendency of projecting causes in the stream of phenomena? It seems that Meyerson, was unfortunately limited in his comprehension of the meaning of metaphysics by his very starting point, namely Comte's system. His approach is too swallow, in the sense that it leaves outside of its scope wider metaphysical perspectives within which any human cognitive engagement with reality should be considered and dealt with. As a conclusion, I would willingly propose an eclectic synthesis of the resources offered by Meyerson and Brunschvicg, the other master of French epistemology. The first thinker is useful to understand the continuity of intellectual tendencies in science and common sense. But the second one gives the opportunity of penetrating the general theoretical frame of the relationship between science, common sense and philosophy.

\section{References}

Bachelard, G. (1949) Le rationalisme appliqué, Paris: Puf.

Bachelard, G. (1953) Le matérialisme rationnel, Paris: Puf.

Bergson, H. (1946) The Creative Mind, translated by Mabelle L. Andison. New York: The Philosophical Library.

Bergson, H (2011) Introduction à la métaphysique (critical edition by Fruteau de Laclos). Paris: Puf.

Boas, G. (1930) A critical Analysis of the Philosophy of Emile Meyerson, Baltimore: The John Hopkins Press.

Brandt, F., Høffding, H., Des Gautries, J.A. (eds.), Correspondance entre Harald Höffding et Emile Meyerson (1939), Copenhague: Einar Munksgaard.

Châtelet, G. (1995) Les enjeux du mobile. Mathématiques, physique, philosophie, Paris: Seuil.

De Broglie, L. (1992) "La physique quantique restera-t-elle indéterministe?", Nouvelles perspectives en microphysique, Paris: Flammarion, pp. 115-143.

Deleuze, G. (1968) Différence et répétition, Paris: Puf. 
Deleuze, G. (1994) Difference and Repetition, New-York: Columbia University Press, 1994, translated by Paul Patton.

Fruteau de Laclos (2006) F. "Émile Meyerson et le Cercle de Vienne: conception anthropologique des sciences contre conception scientifique du monde", Austriaca, 63, 2006, pp. 85-98.

Fruteau de Laclos, F. (2009) Le cheminement de la pensée selon É. Meyerson, Paris: Puf.

Fruteau de Laclos, F. (2009) "De l'architectonique en épistémologie. La philosophie des sciences selon Brunschvicg", Colloque De Brunschvicg à Bachelard, 6 février 2009 (http://www.diffusion.ens.fr/index.php?res=conf\&idconf=2799).

Fruteau de Laclos, F. (2009) L'épistémologie d'Émile Meyerson. Une anthropologie de la connaissance. Paris: Vrin.

Fruteau de Laclos, F. (2013) "La epistemología de los psicólogos. Piaget y los Meyerson", Revista de historia de la psicología, vol. 34, n. 1, pp. 59-80.

Fruteau de Laclos, F. (2014), Émile Meyerson, Paris: Les Belles Lettres.

Fruteau de Laclos, F. (2016), "Pour une epistemology française et la connaissance du sens commun", Revue de métaphysique et de morale, 2, pp. 177-191.

Kuhn, T. (1970) The Structure of Scientific Revolutions, Chicago: University of Chicago Press.

Lévy-Bruhl, L. (1900) La philosophie d'Auguste Comte, Paris: Alcan.

Merleau-Ponty, M. (1960) "Partout et nulle part", Signes, Paris: Gallimard, pp. 238-245.

Merleau-Ponty, M. (1960) “Le philosophe et la sociologie”, Signes, Paris: Gallimard, pp. 176-179.

Merleau-Ponty, M. (1968) The Visible and the Invisible, Evanston: Northwestern University Press, translated by Alphonso Lingis.

Merleau-Ponty, M. (1973) The Prose of the World, translated by John O’Neill. Evanston: Northwestern University Press.

Merleau-Ponty, M. (1994) La nature, Notes de cours du Collège de France, Paris: Seuil. 
Merleau-Ponty, M. (2003) "Eye and Mind", translated by Carleton Dallery, Basic Writings of M. Merleau-Ponty, Thomas Baldwin ed., London \& New York: Routledge.

Metz, A. (1934) Meyerson, Une nouvelle philosophie de la connaissance, 2nd ed., Paris: Alcan.

Metzger, H. (1987) "La philosophie d'Emile Meyerson et l'histoire des sciences", La méthode philosophique en histoire des sciences, Textes 1914-1939, Paris: Fayard.

Meyerson, É. (1912) Identité et réalité, 2nd ed., Paris: Payot.

Meyerson, É. (1930) Identity and Reality, trans. Kate Loewenberg, New York: Macmillan.

Meyerson, É. (1933) Réel et déterminisme dans la physique quantique, Paris: Hermann.

Meyerson, É. (1951), Identité et réalité, Paris: Vrin.

Meyerson, É. (1962) Identity and Reality (IR). Translated by Kate Loewenberg. New York: Dover Publications.

Meyerson, É. (1985) The Relativistic Deduction. Epistemological Implications of the Theory of Relativity (RD), translated by David A. and Mary-Alice Sipfle, With a Review by Albert Einstein and an Introduction by Milic Capek. Dordrecht/Boston/Lancaster: D. Reidel Publishing Company.

Meyerson, É. (1991) Explanation in the Sciences (ES), Dordrecht: Springer Science+Business Media, translated by Mary-Alice and David A. Sipfle.

Meyerson, É. (2008) Essais, Dijon: Association Corpus EUD.

Meyerson, É (2009), Lettres françaises, Paris: CNRS editions

Meyerson, É. (2011) Du cheminement de la pensée (CP), Paris: Vrin.

Piaget, J. (1973) "La causalité selon E. Meyerson". In: Les théories de la causalité, Paris: Puf.

Renault, E. (2001) Hegel, La naturalisation de la dialectique, Paris: Vrin.

Souriau, É: (1939) L'instauration philosophique, Paris: Alcan.

Souriau, É. (1979) L'avenir de la philosophie, Paris: Gallimard. 